\title{
PALEOCHANNELS RELATED TO LATE QUATERNARY SEA-LEVEL CHANGES IN SOUTHERN BRAZIL
}

\author{
Jair Weschenfelder ${ }^{1}$; Iran Carlos Stalliviere Corrêa ${ }^{1}$; Salvador Aliotta ${ }^{2}$ and Ricardo Baitelli ${ }^{1}$ \\ ${ }^{1}$ Universidade Federal do Rio Grande do Sul - Instituto de Geociências \\ Centro de Estudos de Geologia Costeira e Oceânica - CECO \\ (Av. Bento Gonçalves, 9500, 91501-970 Porto Alegre, RS, Brasil) \\ ${ }^{2}$ Instituto Argentino de Oceanografia \\ Complejo CRIBABB \\ (Camino La Carrindanga km 7, 8000 - Bahía Blanca, Argentina) \\ Author corresponding: jair.weschenfelder@ufrgs.br
}

\section{A B S T R A C T}

\begin{abstract}
The geological evolution of the continental shelf and in the coastal zone of southern Brazil during the Quaternary period is addressed in this study. High-resolution seismic records obtained at the Patos Lagoon revealed the presence of channels that deeply dissected the coastal zone before the formation of the modern, low-relief, coastal plain. Two periods of channel incision are inferred, based mainly on seismic records. The paleodrainage paths mapped from the seismic records can be connected with those recognized by previous studies on the adjacent continental shelf and slope. Upstream, the drainage incised mainly into the coastal prism deposited during previous sea-level highstand events. The paleodrainage network, recognized on the coastal plain and continental shelf, represents a rivershelf system, linking the drainage basin to the depositional settings on the marginal basin, bypassing the continental shelf exposed during a forced regression event. The drainage incised into the coastal plain and continental shelf of Rio Grande do Sul played an important role in the basin-margin architecture, facies distribution and accommodation during the Quaternary sea-level fluctuations.
\end{abstract}

\section{RESUMO}

A evolução geológica da plataforma continental e zona costeira do sul do Brasil no período Quaternário é aqui enfocada. Registros sísmicos de alta resolução da Lagoa dos Patos revelaram canais que dissecaram profundamente a região antes da formação da planície costeira atual. Dois períodos de incisão de canal são inferidos, baseados principalmente em registros sísmicos. Os cursos fluviais mapeados por sísmica podem ser conectados àqueles reconhecidos na plataforma continental adjacente por estudos anteriores. À montante, a incisão da drenagem ocorreu principalmente no prisma sedimentar costeiro depositado durante eventos pretéritos de nível do mar alto. A rede de paleodrenagem, reconhecida na planície costeira e na plataforma continental, representa um sistema de ligação da bacia de drenagem continental aos depocentros da bacia marginal, sobrepassando a plataforma continental exposta durante uma regressão forçada. A incisão da drenagem na planície costeira e plataforma continental do Rio Grande do Sul desempenhou um papel importante na arquitetura marginal, distribuição de fácies e no espaço de acomodação durante as flutuações do nível do mar no Quaternário.

Descriptors: Seismic survey, Coastal evolution, Incised valleys, Patos Lagoon.

Descritores: Levantamento sísmico, Evolução costeira, Vales incisos, Laguna dos Patos.

\section{INTRODUCTION}

The decisive influence of sea-level variations on the geological evolution of marginal basins around the world has long been recognized. The present basin margin morphologies and architectures are mainly the result of a series of glacial-interglacial cycles (MEIJER, 2002).
Several studies suggest that the Quaternary evolution of the coastal plain and adjacent continental shelf of Rio Grande do Sul (RS) is mainly determined by the sea-level (CORRÊA, 1986, 1995, 1996; DILLENBURG et al., 2004; MARTINS et al., 1985, 1996; TOMAZELLI; VILLWOCK, 2000; VILLWOCK; TOMAZELLI, 1995; VILLWOCK et al., 1986). 
The sedimentary systems along the southern Brazilian marginal basins have been strongly affected by sea-level cycles. The present physiography of the coastal plain and continental shelf is mainly the result of Quaternary high-frequency, glacio-eustatic, sealevel changes.

The close association between sea level variation and fluvial incision on continental shelves has been demonstrated in several papers (BLUM; TÖRNQVIST, 2000; CONTI; FURTADO, 2009; HORI et al., 2002; KOSS et al., 1994). Basically, during an event of relative fall in sea-level, the channels and valleys formed by fluvial systems extend their limits basinward, widening the exposed shelf and eroding into underlying strata. The exposed shelf (the "newly formed coastal plain"), usually composed of unconsolidated sediments, is incised by valleys linking the drainage basin onland to the depositional settings on the marginal basin offshore. The coastal prism, deposited during a previous sea-level highstand event, is usually deeply dissected.

Tracking the spatial distribution of the paleodrainage network and the unconformities, produced by such erosional processes during a fall in sea-level, is useful to improve the current models of sequence stratigraphy proposed for margin-shelf settings.

In this paper the paleodrainage systems are mapped on the coastal plain and the continental shelf of RS (Fig. 1). The former drainage systems are reconstructed mainly from the paleoincisions observed in high-resolution seismic data. Timing of the incision of the paleodrainage networks is discussed. The geological evolution of the coastal plain and continental shelf of RS during the Quaternary is also addressed.

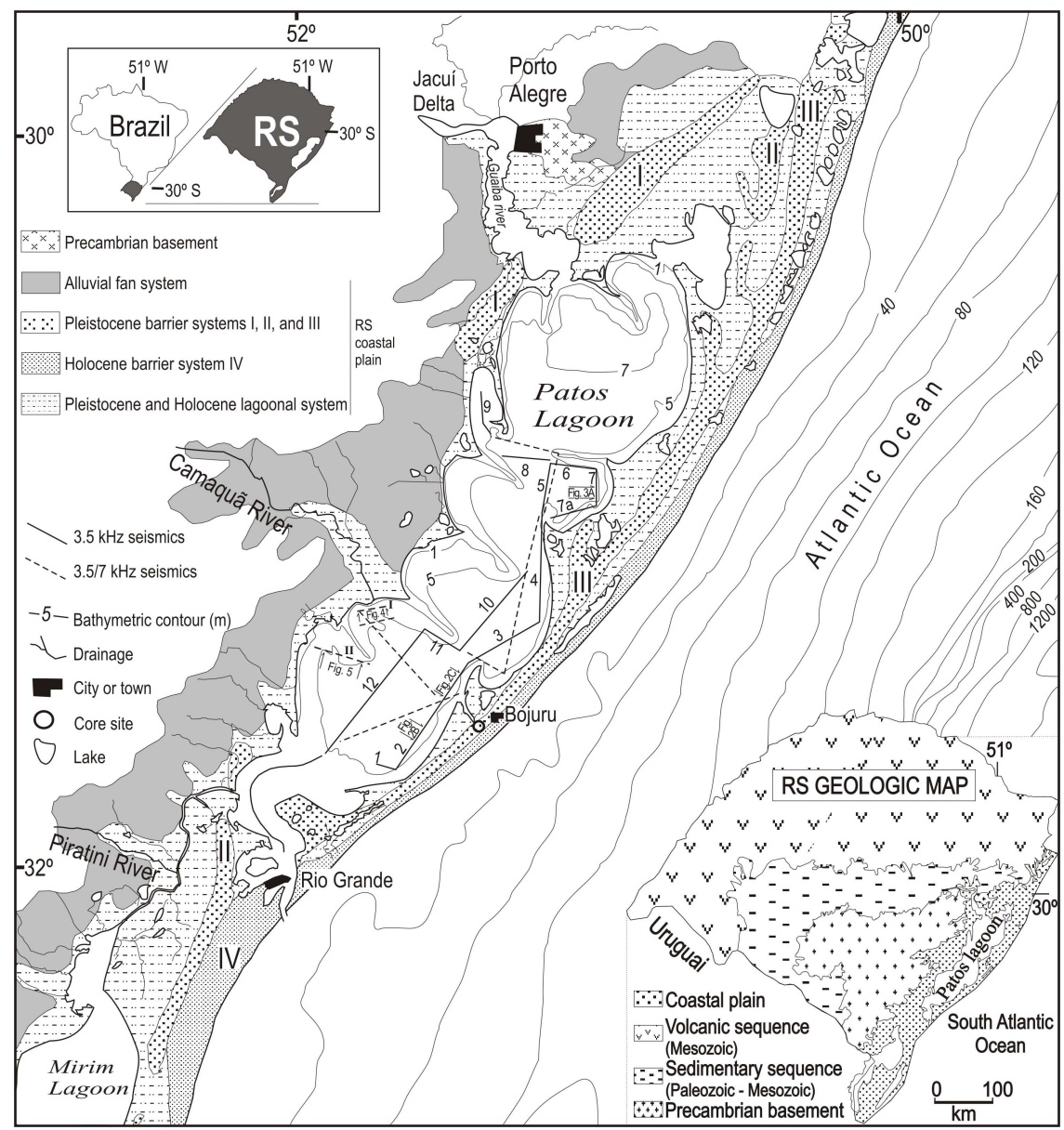

Fig. 1. Location of the study area and seismic records analyzed. RS geological map modified from Villwock et al. (1986). Coastal plain geology modified from Tomazelli and Villwock (2000). Bathymetric contours from Corrêa (1996) and Toldo-Jr et al. (2000). 


\section{Geological Outline}

The coastal plain of RS represents the upper part of the Pelotas marginal basin. Four lagoon-barrier type depositional systems, related to transgressiveregressive events of the Late Quaternary period, have been recognized on the RS coastal plain (TOMAZELLI; VILLWOCK, 2000; VILLWOCK; TOMAZELLI, 1995). A correlation between the sealevel highstands and major peaks of the oxygen isotope curve has been established by Villwock and Tomazelli (1995), which should confirm the correlation between sea level oscillations and climate changes (ZAZO et al., 2008).

Although several transgressive and regressive events have left their distinct topographic, depositional, erosional and sedimentary imprint, the present morphology of the RS continental shelf is in general homogeneous. It is characterized by a smooth morphology with a very gentle gradient (1.3-1.4 $\mathrm{m} / \mathrm{km}$ ) and an average width of $125 \mathrm{~km}$. The northern section is narrow and homogeneous, whereas the southern section is wider and gently dissected. The usually smooth shelf morphology is interrupted, mainly in the south portion, by sand bodies such as sand waves. Associated with these sand bodies are elongated bioclastic deposits which have been interpreted as paleoshoreline indicators (CORRÊA, 1996). The presence of marine terraces with considerably steeper slopes throughout the shelf has been interpreted as a record of periods of stabilization in the sea-level during the Holocene transgressive event (CORRÊA, 1996).

According to Corrêa (1986), the Holocene transgression began approximately $17.5 \mathrm{ky} \mathrm{BP}$, when the sea-level was $120 \mathrm{~m}$ lower than the present level. Before this event, the present inner shelf surface was subaerial coastal plain, subject to erosion and to fluvial incision. Beach ridges, consisting of coarse sand, were formed along the paleocoastline; fine sand was deposited on the inner shelf, whereas clay and clayey sand dominated the outer shelf and the upper slope. Around $5 \mathrm{ky} \mathrm{BP}$, the sea was 5-6 $\mathrm{m}$ above the present level during the Holocene Climatic Optimum. During this phase, the drainage channels became shorter landwards and fine sediments were deposited in deeper waters, while reworking transgressive sands in the coastal zone. Paleocoastline stabilization is marked by bioclastic gravels and heavy mineral concentrations.

Nowadays, the RS coastal plain is characterized by wide lowlands covering an area around 33,000 sq km, bordering highlands to the west. The main physiographic feature is the Patos Lagoon, with $240 \mathrm{~km}$ length and an average width of $40 \mathrm{~km}$ (Fig. 1). The lagoonal deposits consist of marginal sands and muddy sediments (up to $6 \mathrm{~m}$ thick) in the interior of the lagoon (TOLDO-JR et al., 2000). The lagoon receives a great river discharge and transports it to the Atlantic Ocean through a single tidal inlet near the city of Rio Grande. No evidence for severe storms in this area during the Holocene has been reported, and the tidal amplitude averages $<40 \mathrm{~cm}$.

\section{Methods}

This study is primarily based on the analysis of seismic reflection profiles obtained in the Patos Lagoon. It focuses on the identification and mapping of the former drainage network that dissected the area of study. The established geological framework for the coastal and marine geology of southern Brazil has corroborated the achievement of some of the goals set for this study.

A $3.5 \mathrm{kHz}$ seismic-reflection data survey was performed in the Patos Lagoon (Fig. 1; profiles 1 to 12) in December, 2002. The cruise was carried out aboard the research vessel Larus of the Fundação Universidade do Rio Grande. The positioning of the seismic lines was determined by a DGPS system linked to the subbottom profiler system. The seismic equipment used was a GeoAcoustics subbottom profiler, consisting of a GeoPulse transmitter (model 5430A), a GeoPulse receiver (model 5210A), a 132B transducer array (4 mount), a graphic recorder EPCGSP-1086, a GeoPro processor system and seismic data acquisition software. The transducers were mounted on a plate at the end of a vertical, gimbaled staff supported by a mounting pad fixed over the vessel's side. The dataset was saved in analogical and digital formats.

In addition, seismic sections $(3.5$ and $7 \mathrm{kHz})$ obtained at the Patos Lagoon during a former research cruise (TOLDO-JR et al., 2000) were analyzed (Fig. 1; dashed line seismic sections). The data survey was performed using a shallow seismic system RTT 1000, from Raytheon, consisting of a 719 C RTT recorder, a $3.5 / 7 \mathrm{kHz}$ transducer, and a PTR $106 \mathrm{C}$ transceiver.

The analysis and interpretation of the seismic data were based on the configuration of the reflectors, according to the general concepts established in the field of seismic stratigraphy (MITCHUM-JR. et al., 1977). We assumed velocity of sound in sediments of $1,650 \mathrm{~m} / \mathrm{s}$ to evaluate the thickness of the sedimentary packages by converting travel times into meters (JONES, 1999).

\section{RESULTS}

The analysis of the seismic profiles reveals the architectural elements that make up the sedimentary pile deposited in the Patos Lagoon during the Late Quaternary. These elements are identified 
through the configurations of the reflectors, namely external geometry, lateral termination and internal configuration.

Well delineated paleochannels, or other features indicating their occurrence, were identified in almost all the seismic profiles analyzed. However, the records of the $3.5 \mathrm{kHz}$ seismic profiles 1 to 12 (Fig. 1) provided a better resolution and deeper penetration than the 3.5 and $7 \mathrm{kHz}$ sections obtained previously (dashed line seismic section in Figure 1).

Systematic mapping of the seismic surfaces makes clear the presence of two distinct, well-defined cut-and-fill paleochannel systems (Fig. 2). The older paleochannel system is buried by a sedimentary unit up to $8 \mathrm{~m}$ thick (Figs 2B, D), whereas the younger paleochannel system is blanked by a centimeter-thin veneer of sediments (Figs 2C, E; Fig. 3). The seismic reflectors of the older paleochannel system are intersected by the reflectors of the younger, indicating the relative timing of incision, i.e., the incision and infilling of the older paleochannel system (Fig. 2A). The uppermost reflectors of the seismic facies representing the sedimentary infill of the younger paleochannel system are truncated in some places by reflectors attributed to the modern lagoon bottom (Figs $2 \mathrm{C}, \mathrm{E})$.

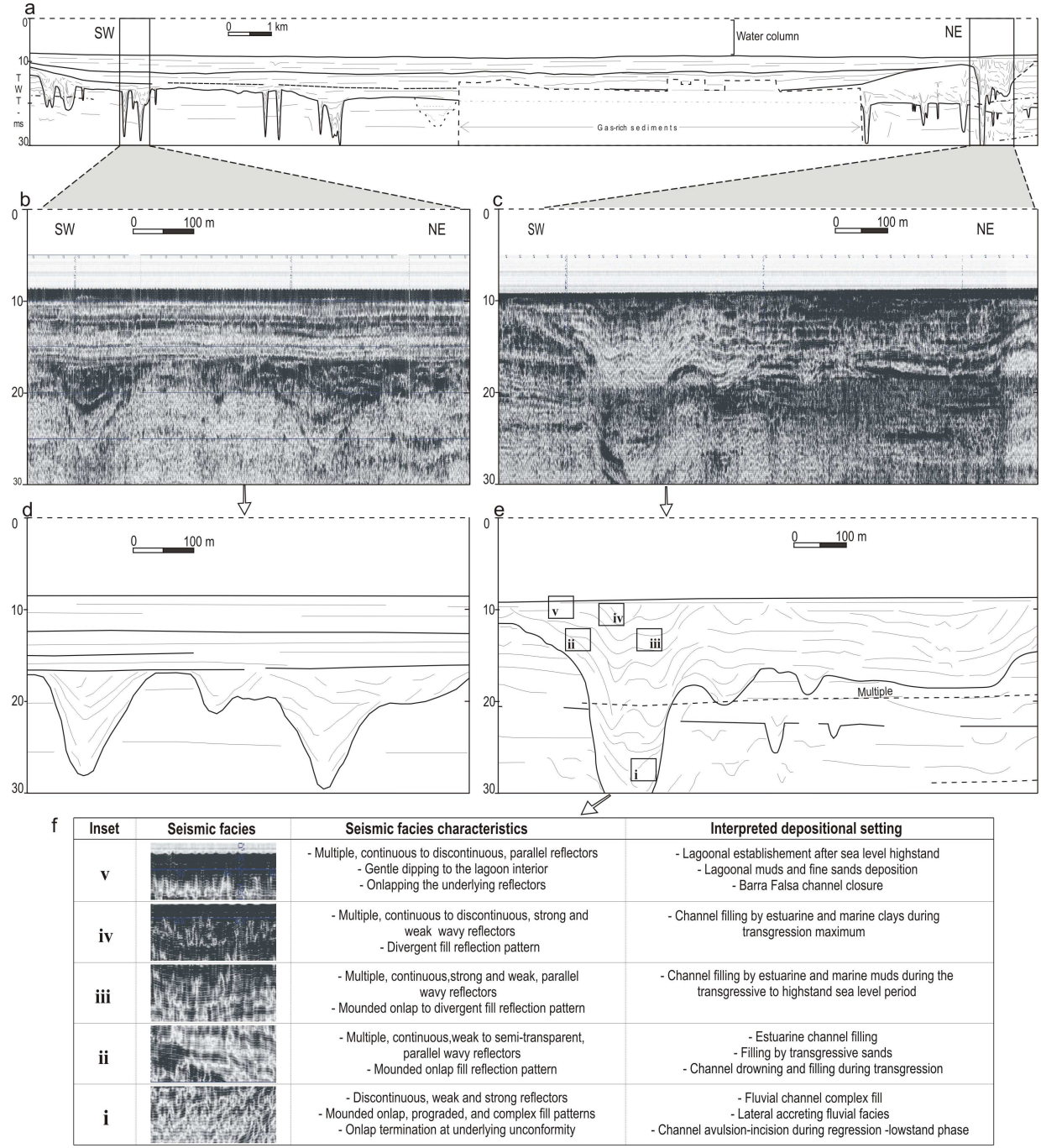

Fig. 2. Main seismic reflectors mapped from profile 2 (A). Selected section from profile 2 (B and C), showing main seismic reflectors ( $D$ and $E$ ), and the characteristics of channel fill seismofacies - insets i to $\mathrm{v}$ - are also showed (F) with the synthesis of the results (after Weschenfelder et al., 2005, 2008b). Depths to water surface in two-way traveltime (twt), in milliseconds (ms). 
Profile 2 is about $38 \mathrm{~km}$ long and was obtained roughly parallel to the eastern border of the Patos Lagoon, in a southwest-to-northeast direction. The water depths along the profile are around $6 \mathrm{~m}$, except at the southwestern and northeastern ends of the profile, where the water depths decrease to around $5 \mathrm{~m}$, due to the proximity of the lagoonal margin.

Various buried channels of the older system are detected in profile 2 (Fig. 2A). They are some hundred of meters wide and the sedimentary infill reaches thicknesses up to $15 \mathrm{~m}$. Paleochannels are infilled with seismic facies units filling a negative relief in the underlying strata. The underlying reflections are mainly parallel to subparallel and continuous to discontinuous, showing truncation along the continuous basal surface of the channels. The upper reflectors of the seismic facies filling up these paleochannels are truncated by a well-marked, strong and continuous reflector of the overlying strata. The overlying strata are composed of continuous, parallel to subparallel, gently dipping reflectors (Figs 2B, D).

The largest paleochannel in profile 2 is about $1.5 \mathrm{~km}$ wide and the sedimentary channel-fill sediments are at least $20 \mathrm{~m}$ thick (Figs 2C, E). This large paleochannel is included in the younger group of paleochannels. The underlying strata are mainly composed of seismic facies with parallel and subparallel, continuous to discontinuous reflectors (Fig. 2E). Truncation of the seismic reflectors marks the basal surface of the channel. The lowermost channel fill seismic facies presents dipping reflectors throughout the entire channel. Discontinuous, weak and strong reflectors delineate mounded onlap, prograded, and complex fill patterns onlapping the underlying unconformity (Fig. 2E, inset i). A laminated to acoustically transparent seismic facies delineates a mounded onlap pattern (Fig. 2E, inset ii). The seismic facies of insets iii and iv are similar. However, the upper fill seismic facies unit presents more undulating, stronger to opaque, reflectors. The youngest seismic-facies unit is marked by acoustically laminated deposits onlapping the underlying unit at a very low angle. The reflectors are continuous, parallel to semiparallel, dipping gently to the lagoon interior. In some places the upper reflectors are truncated by the lagoon bottom reflector (Fig. 2E, inset v). As indicated by the radiocarbon dating (WESCHENFELDER et al., 2008b), the main period of sedimentary filling of this channel is Holocene.

Profile 7 (N-S) extends for over $10 \mathrm{~km}$. It was obtained along the eastern lagoon margin, in a north-to-south direction. The water along the profile is around $5 \mathrm{~m}$ deep except at the southern end of the profile, where the ship crossed a lagoon terrace covered by about $2 \mathrm{~m}$ of water. Various paleochannels were mapped on this seismic line. The base of the channels is delineated by a strong reflector truncating the reflectors of the underlying strata (Figs 3A, B).

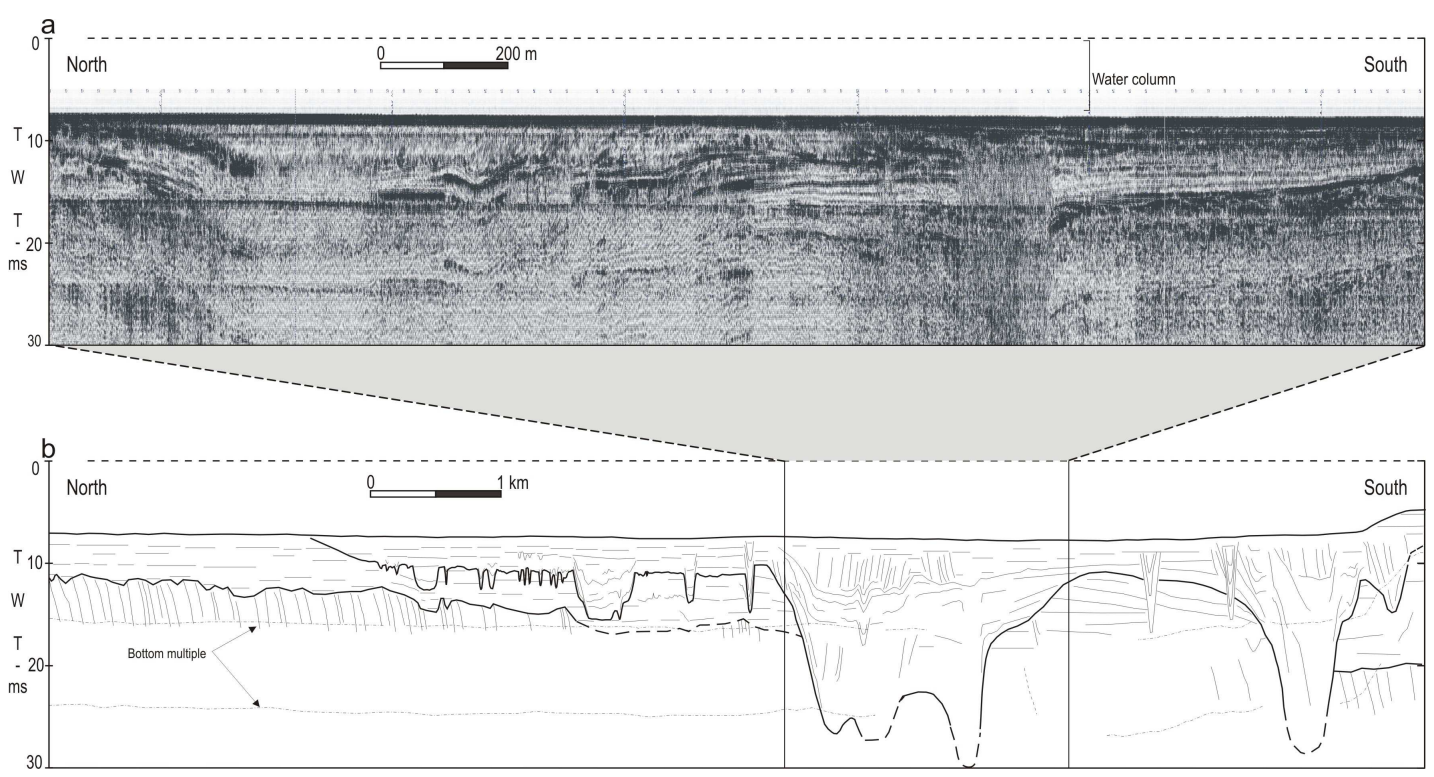

Fig. 3. Representative sector of profile 7 (A) and the main seismic reflectors mapped out from the records (B). Depths to water surface in two-way traveltime (twt), in milliseconds (ms). 
The most prominent paleochannel is about 2 $\mathrm{km}$ wide and the sedimentary filling is at least $20 \mathrm{~m}$ thick (Figs 3A, B). This large paleochannel is adjacent to another one of the same magnitude, located at the south end of the profile. Further, various paleochannels with widths ranging from a few meters to hundreds of meters and with depths ranging from approximately 1 to $4 \mathrm{~m}$ are present throughout the profile (Fig. 3B). In some places the uppermost reflectors are truncated by reflectors attributed to the lagoon bottom, similar to those found in a previously mentioned paleochannel of profile 2 .

Profile I was obtained across the active intralagoonal delta of the Camaquã River, in a southwest-to-northeast direction. The southwestern end of the profile reveals the presence of a wide buried paleochannel, more than $1 \mathrm{~km}$ wide and up to $7 \mathrm{~m}$ deep. Profile I showed a larger buried channel at its center, but the presence of gas-rich sediments formed an acoustic blanking layer, which hindered its exact delineation (Fig. 4).

Profile II was also recorded on the western border of the lagoon, in a southeast-to-northwest direction. It is located about $15 \mathrm{~km}$ south of the present mouth of the Camaquã River (Fig. 1). Water depths range from about $3 \mathrm{~m}$ at the northwest end of the profile to $5 \mathrm{~m}$ at the southeast end of the profile. The records show a wide (up to $2 \mathrm{~km}$ ) and deep (around $10 \mathrm{~m}$ ) buried paleovalley flanked by a strong, irregular and undulating, well-marked reflector. The buried paleochannel is infilled in the middle reaches by a thick sedimentary unit, which presents no clear evidences of channel cutting (e.g., by the Camaquã channel) (Fig. 5).

It is worthwhile to mention that acoustic anomalies, due to gas-rich sediments are present in some sectors of the seismic profiles. The gas trapped appears as a strong reflection, somewhat masking the underlying reflectors (JUDD; HOVLAND, 1992; WESCHENFELDER et al., 2006). The profiles far from the lagoon margin are especially strongly affected by this acoustic phenomenon (e.g., profiles 8 , 10 and 12), contrasting with those situated near the margin (e.g., profiles 2, 7 and 11). Moreover, the shallow water depths contributed to low signal penetration in some sectors, associated with the recurrent multiple reflector of the lagoon bottom.

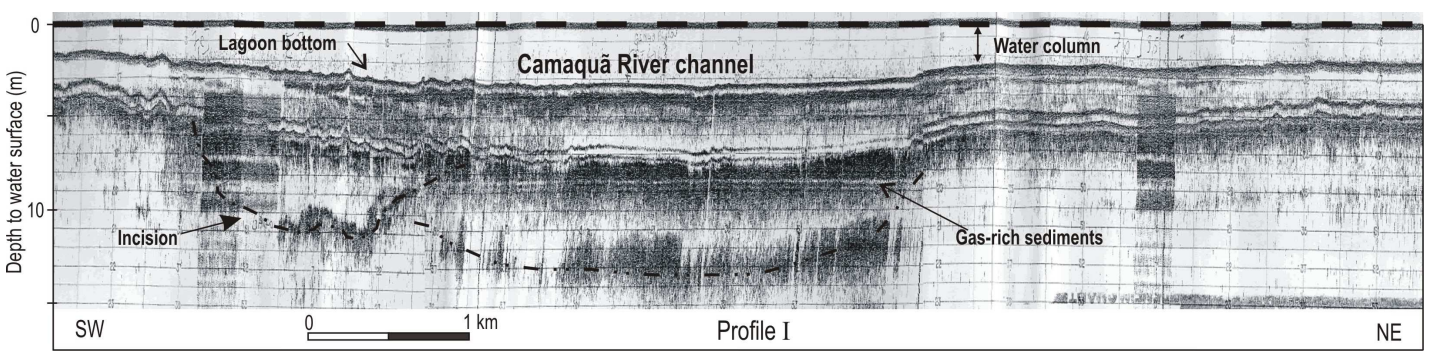

Fig. 4. Profile I ( $7 \mathrm{kHz})$ through the Camaquã intralagoonal delta, showing the former and present course of the river. Distances to water surface in meters $(\mathrm{m})$.

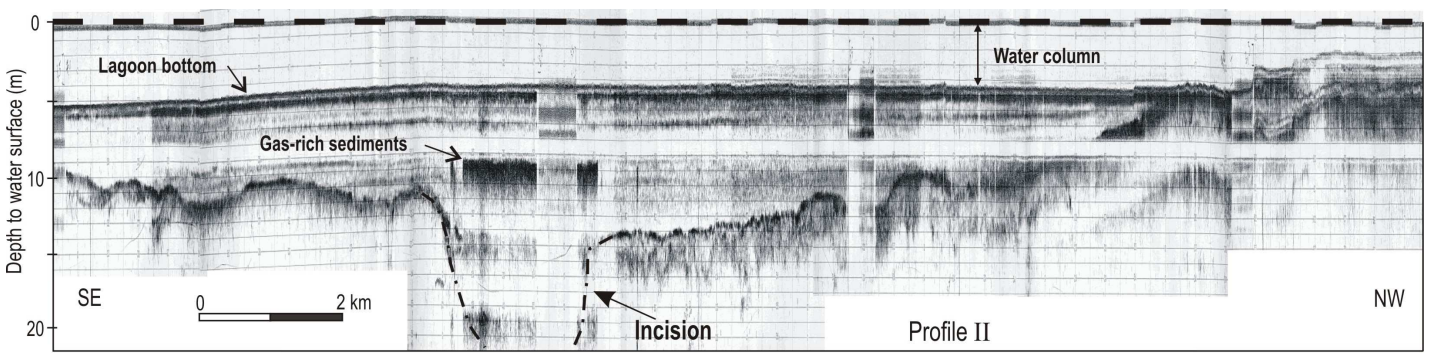

Fig. 5. Profile II ( $7 \mathrm{kHz})$ obtained near the mouth of the Camaquã River. A wide buried channel is shown. Distances to water surface in meters $(\mathrm{m})$. 


\section{Discussion}

Coastal morphology, prior to a transgression event plays a decisive role in coastal evolution and hence on the actual coastal configuration (BELKNAP; KRAFT, 1985). The present continental shelf of RS shows a homogeneous and smooth morphology with a very gentle gradient, broadly reflecting the regional former coastal plain topography prior to the Holocene postglacial marine transgression (DILLENBURG et al., 2000).

The preservation potential of the Holocene sedimentary records along the north and central coast of RS was addressed by DILLENBURG et al. (2000). The study shows, for the north coast that the preexisting Pleistocene morphology was deeply dissected by fluvial channels before the Holocene marine transgression, contrasting with evidence of a smooth and dissection-free morphology in the central coast near the town of Bojuru. The study also indicates that the depth of shoreface erosion ranges from 3 to $10 \mathrm{~m}$ for the present RS northern coast. This value was estimated assuming a transgressing sea in a shoreface retreatment model (REINSON, 1992).

Our seismic data indicate that the central part of the Rio Grande do Sul coastal plain was deeply dissected during Late Pleistocene lowstands by fluvial channels prior to transgressive events (WESCHENFELDER et al., 2005, 2008a,b). Two paleochannel systems can be established in the area of study. The older paleochannel system is relatively deeply buried by a sedimentary package up to $8 \mathrm{~m}$ thick (e.g., Figs 2B, d). A younger paleochannel system practically crops out on the bottom of the Patos Lagoon (e.g., Figs 2C, E; Fig. 3). The channel filling of the younger drainage system is Holocene, as indicated by radiocarbon dating (WESCHENFELDER et al., 2008b). The channel incisions are thus related to the Last Glacial Maximum (Marine Isotope Stage) (MIS 2) of the Late Pleistocene, when the sea-level fell to a depth of $120 \mathrm{~m}$ below its present position. The older paleochannel system formation and filling would, therefore, be related to a previous regressivetransgressive event of the Pleistocene, e.g. MIS 6 (WESCHENFELDER et al., 2008a).

The two paleochannel systems just mentioned (Late Pleistocene; Latest PleistoceneHolocene) were mapped from seismic records. The drainage lines were extended through the continental shelf to the shelf edge by means of morphostructural data (CORRÊA, 1996; MARTINS et al., 1996). Landwards, the paleodrainage lines were linked with the main present river courses (Fig. 6).

The Camaquã River is the main drainage source entering the midwestern part of the Patos Lagoon. The upper and middle courses of the main rivers reaching the coastal plain of RS (e.g., the Piratini, Camaquã and Jacuí Rivers) (Fig. 1) have maintained a relatively fixed position during the Quaternary. They drain a stable Precambrian basement and, from Porto Alegre northwards, the Paleozoic to Mesozoic volcano-sedimentary sequences of the Paraná basin. However, the lower courses of these rivers have drained an unconsolidated sedimentary coastal plain.

The lower course of the Camaquã River has cut mainly into alluvial fans of the Pliocene and Pleistocene. The onset of channel incision probably occurred during the Early Pleistocene. It has been excavated principally since the Middle Pleistocene and especially during the $130 \mathrm{~m}$ sea-level lowstand that occurred during the forced regression related to the maximum of the Wisconsin Glaciation. During the transgressive episodes following the glaciations, the Camaquã incised valley was a depositional setting for sediments from coastal and continental environments, deposited in a multitude of sedimentation cycles.

A paleochannel inlet between the Patos Lagoon and the Atlantic Ocean was hypothesized by Toldo-Jr. et al. (1991, 2000). According to this hypothesis, the narrow and shallow reentrance on the lagoon coast near Bojuru (called 'Barra Falsa channel') is a morphological inheritance from a Holocene inlet. When the axis of this inlet is extended into the lagoon it intercepts profile 2 , just where a prominent paleochannel occurs (Figs 2c, e). Hence, the entrance to the lagoon near Bojuru most probably represents a morphological feature left over from a former wide channel connecting the Patos Lagoon to the Atlantic Ocean. The Holocene channel filling sequence was determined by sea-level changes, climatic oscillations and coastal barrier-inlet development (WESCHENFELDER et al., 2008b).

Two placer deposits, located backshore, occur in the area of study. The placer located between the marine coastline and the town of Bojuru, known as the Bojuru placer, has been related to ancient deltaic sediments of the Camaquã River, which were reworked by coastal processes during sea-level highstands (DILLENBURG et al., 2004). The second placer is located at approximately the same latitude as the place where profile 1 intercepts profile 2 , presenting similar characteristics to the Bojuru placer. We have, therefore, envisaged two Late Pleistocene/Holocene paths related to the former Camaquã River. They were delineated by linking the present river course to the paleochannel incisions mapped out from the seismic records and, continuing basinward, across the adjacent continental shelf (Fig. $6)$.

The paleochannels mapped out from profile 7 probably correspond to the former course of the Jacuí River (Fig. 3). In profile 7 the main 
paleochannels cut through the entire recorded sedimentary pile, similar to the sequence of events recorded in the Camaquã paleochannel in profile 2 (Figs 2C, E). The smaller paleochannels occurring in profiles 2 and 7 , usually cutting only the uppermost strata, could be tributaries of the main river courses or independent smaller drainage courses.
The Camaquã and Jacuí rivers excavated deep, wide incisions in the coastal plain, triggered by the last forced regression event (Wisconsin Glaciation) (Last Glacial Maximum). These channels probably represented an important river-shelf bypassing system, linking the drainage basin to the west with the depositional settings to the east.

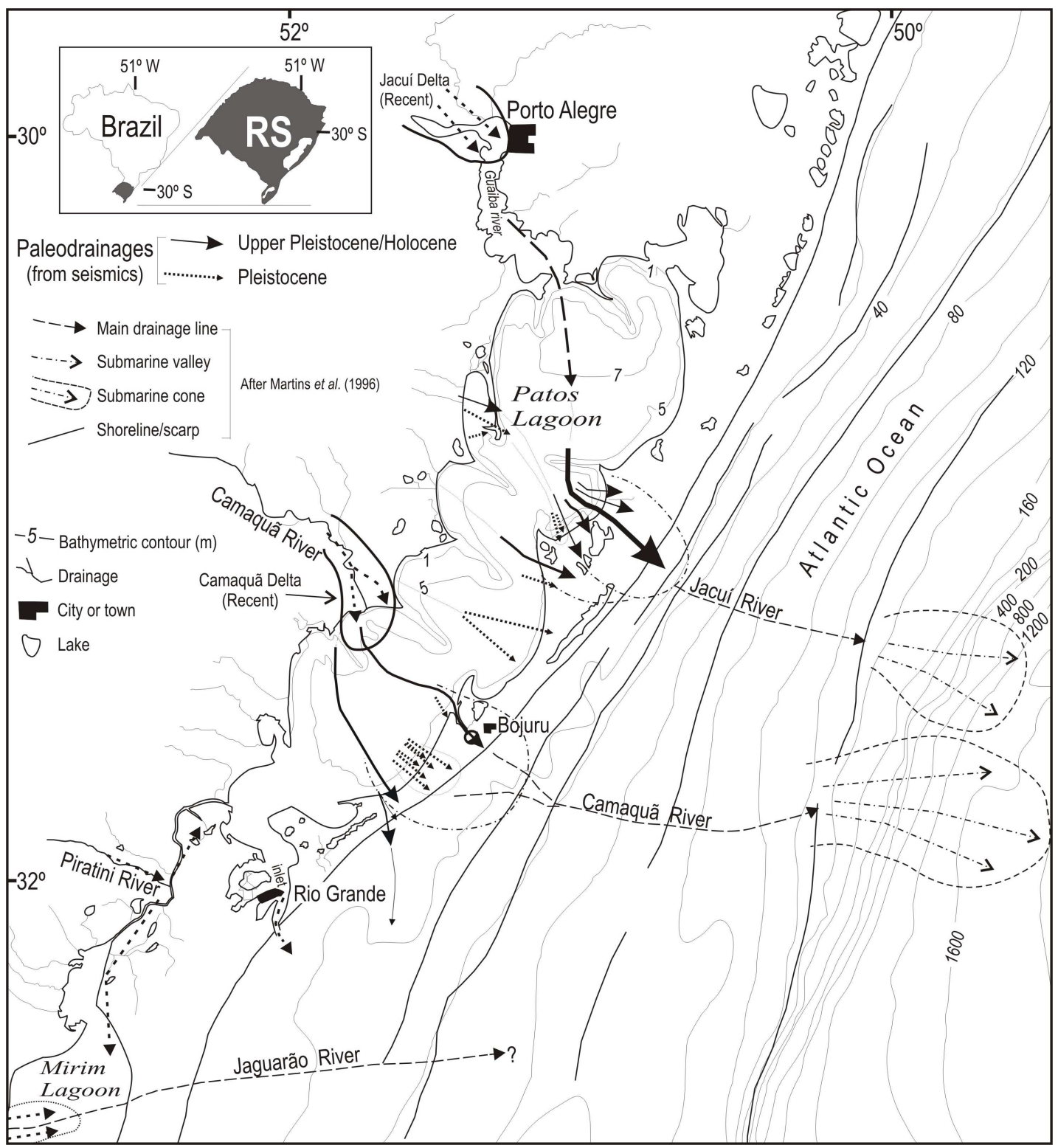

Fig. 6. Paleodrainage network mapped out from the seismic records. Shelf and slope features modified from Martins et al. (1996). 
In general terms, the RS coastal plain and the adjacent continental shelf were deeply dissected before the transgressive events (ABREU; CALLIARI, 2005). The paleochannels that dissected the shelf before the transgressive events can be linked through the coastal plain to the present river network inland. The paleodrainage map of Figure 6 represents former river-shelf systems, linking the drainage basin inland to the depositional settings in the Pelotas marginal basin.

The bypassing discharge of the younger drainage system (Latest Pleistocene/Holocene in Figure 6) fed a complex of delta systems installed on the shelf edge of RS during the sea-level lowstand that lasted until the end of the last glaciation at around 17.5 ky (ANGULO; LESSA, 1997; DILLENBURG et al., 2004). The Holocene transgressive post-glacial event drowned the Pleistocene incised paleochannels, infilling them and, finally, closing the inlets formerly existing between the Patos Lagoon and the Atlantic Ocean. The contours of the Patos Lagoon were thus established and there remains the single inlet to the south. Presently, the lagoon captures a significant river discharge and conducts it to the ocean through a large inlet near the city of Rio Grande.

\section{Conclusions}

The continuous seismic-reflection profiles, obtained at the Patos Lagoon, allowed us to recognize the shallow architectural elements that built up the sedimentary pile accumulated on the Rio Grande do Sul coastal plain.

Incision networks deeply dissected the coastal plain and the continental shelf before the installation of the subsequent postglacial Holocene transgressive events. The paleodrainage networks represented river-shelf systems, linking the drainage basin inland and the depositional setting of the Pelotas marginal basin, bypassing the continental shelf exposed by forced regression events.

The two drainage systems identified through the seismic records were formed during two distinct periods. The sedimentary filling of the younger paleochannel system is Holocene, as indicated by absolute radiocarbon dating. Its incision is related to the last forced regression of the end of the Pleistocene period. The incision and the filling of the older channel system are most probably related to a previous transgression-regression event of the Late Pleistocene.

The drainage network incised into the Rio Grande do Sul coastal plain and the adjacent continental shelf played an important role in the basinmargin's architecture, the facies distribution and the spatial accommodation that occurred during the Quaternary.

\section{ACKNOWLEDGMENTS}

Support for this research project has been provided by the Conselho Nacional de Desenvolvimento Científico e Tecnológico - CNPq Brasil (Proc. 560661/2008-8).

\section{REFERENCES}

ABREU, J. G. N.; CALLIARI, L. J. Paleocanais da plataforma continental interna do Rio Grande do Sul: evidências de uma drenagem fluvial pretérita. Rev. Bras. Geofís., v. 2, n. 23, p. 123-132, 2005.

ANGULO, R. J.; LESSA, G. C. The Brazilian sea-level curves: a critical review with emphasis on the curves from Paranaguá and Cananéia regions. Mar. Geol., v. 140, p. 141-166, 1997.

BELKNAP, D. F.; KRAFT, J. C. Influence of antecedent geology on stratigraphic preservation potential and evolution of Delaware's Barrier Systems. Mar. Geol., v. 63, p. 235-262, 1985.

BLUM, M. D.; TÖRNQVIST, T. E. Fluvial responses to climate and sea-level change: a review and look forward. Sedimentology, v. 47 (Suppl. 1), p. 2-48, 2000.

CONTI, L. A.; FURTADO, V. V. Topographic registers of paleo-valleys on the southeastern Brazilian continental shelf. Braz. J. Oceanogr., v. 57, n. 2, p. 113-121, 2009.

CORRÊA, I. C. S. Evidence of sea-level fluctuation on the Rio Grande do Sul continental shelf, Brazil. Quaternary of South America and Antarctic Peninsula, v. 40, p. 237-249, 1986.

CORRÊA, I. C. S. Les variations du niveau de la mer durant les derniers 17.500 ans BP: l'exemple de la plate-forme continentale du Rio Grande do Sul-Brésil. Mar. Geol., v. 130, p. 163-178, 1995.

CORREA, I. C. S. Processus dynamiques dans la distribution des sédiments de la plate-forme continentale du Rio Grande do Sul (Brésil). Geodinam. Acta, v. 4, n. 9, p. 161-169, 1996.

DILLENBURG, S. R.; ROY, P. S.; COWELL, P. J.; TOMAZELLI, L. J. Influence of antecedent topography on coastal evolution as tested by the Shoreface Translation-Barrier Model (TSM). J. coast. Res., n. 16, p. $71-81,2000$.

DILLENBURG, S. R.; TOMAZELLI, L. J.; BARBOZA, E. G. Barrier evolution and placer formation at Bujuru, Southern Brazil. Mar. Geol., n. 203, p. 4.3-56, 2004.

HORI, K.; SAITO, Y.; ZHAO, Q.; WANG, P. Control of incised-valley fill stacking patterns by accelerated and decelerated sea-level: the Changjiang example during the last deglaciation. Geo-Marine Letts, v. 22, p. 127-132, 2002.

JONES, E. J. W. Marine Geophysics. Chichester: Wiley \& Sons (Ed.), $1999.520 \mathrm{p}$.

JUDD, A. G.; HOVLAND, M. The evidence of shallow gas in marine sediments. Continent. Shelf Res., v. 10, n. 12, p. 1081-1095, 1992.

KOSS, J. E.; ETHRIDGE, F. G.; SCHUMM, S. A. An experimental study of the effects of base-level change on fluvial, coastal plain and shelf systems. J. sediment. Res., v. 64, n. 2, p. 90-98, 1994. 
MARTINS, L. R.; ARIENTI, L. M.; MOURA, Y. A SANTOS, N. M. Contribuição ao estudo da borda da plataforma continental do Rio Grande do Sul. Pesquisas, n. 17, p. 24-44, 1985.

MARTINS, R. M.; URIEN, C. M.; CORRÊA, I. C. S.; MARTINS, I. R. Late Quaternary processes along the Rio Grande do Sul Continental shelf (Southern Brazil). Notas técn., Porto Alegre, n. 9, p. 62-68, 1996.

MEIJER, X. D. Modelling the drainage evolution of a rivershelf system forced by Quaternary glacio-eustasy. Basin Res., n. 14, p. 361-377, 2002.

MITCHUM-JR., R. M.; VAIL, P. R.; SANGREE, J. B Seismic stratigraphy and global changes of sea-level, Part 6: Stratigraphic interpretation of seismic reflection patterns in depositional sequences, In: PAYTON, C.E. (Ed.). Seismic Stratigraphy - Applications to hydrocarbon exploration. AAPG Memoir, n. 26, p. 117 133, 1977.

REINSON, G. E. Transgressive Barrier Island and Estuarine Systems. In: WALKER, R.G., JAMES, N.P. (Ed.), Facies models - Response to sea-level change. Stittsville: Geological Association of Canada, 1992. p. 170-194.

TOLDO-JR., E. E.; AYUP-ZOUAIN, R. N.; CORRÊA, I. C. S.; DILLENBURG, S. R. Barra falsa: hipótese de um paleocanal holocênico de comunicação entre a laguna dos Patos e o Oceano Atlântico. Pesquisas, v. 2, n. 18, p. 99-103, 1991.

TOLDO-JR., E. E.; DILLENBURG, S. R.; CORRÊA, I. C S.; ALMEIDA, L. E. S. B. Holocene sedimentation in Lagoa dos Patos lagoon, Rio Grande do Sul, Brazil. J. coast. Res., n. 16, p. 816-822, 2000.

TOMAZELLI, L. J.; VILLWOCK, J. A. O Cenozóico no Rio Grande do Sul: Geologia da Planície Costeira. In: HOLZ, M.; DE ROS, L.F. (Ed.). Geologia do Rio Grande do Sul, p. 375-406, 2000.
VILLWOCK, J. A.; TOMAZELLI, L. J. Geologia costeira do Rio Grande do Sul. Notas técn., Porto Alegre, 8, p. 1$45,1995$.

VILLWOCK, J. A.; TOMAZELLI, L. J.; LOSS, E. L.; DEHNHARDT, E.A.; HORN FILHO, N.O.; BACHI, F.A.; DEHNHARDT, B.A. Geology of the Rio Grande do Sul Coastal Province. Quaternary of South America and Antarctic Peninsula, n. 4, p. 79-97, 1986.

WESCHENFELDER, J.; CORRÊA, I.C.S.; ALIOTTA, S. Elementos arquiteturais do substrato da Lagoa dos Patos revelados por sísmica de alta resolução. Pesquisas Geociênc., v. 2, n. 32, p. 57-67, 2005.

WESCHENFELDER, J.; CORRÊA, I. C. S.; ALIOTTA, S.; PEREIRA, C. M.; VASCONCELLOS, V.E.B. Shallow gas accumulation in sediments of the Patos Lagoon, Southern Brazil. An. Acad. Bras. Ciênc., v. 3, n. 78, p. 607-614, 2006.

WESCHENFELDER, J.; CORRÊA, I. C. S.; TOLDO-JR., E. E.; BAITELLI, R. Paleocanais como indicativo de eventos regressivos quaternários no nível do mar no sul do Brasil. Rev. Bras. Geof., v. 3, n. 26, p. 367-375, 2008a.

WESCHENFELDER, J.; MEDEANIC, S.; CORRÊA, I. C. S.; ALIOTTA, S. Holocene paleoinlet of the Bojuru region, Lagoa dos Patos, southern Brazil. J. coast. Res., v. 1 , n. 24, p. 99-109, 2008b.

ZAZO, C.; DABRIO, C. J.; GOY, J. L.; LARIO, J; CABERO, A.; SILVA, P. G.; BARDAJI, T.; MERCIER, N.; BORJA, F.; ROQUERO, E. The coastal archives of the last $15 \mathrm{ky}$ in the Atlantic-Mediterranean Spanish linkage area: Sea level and climate changes. Quat. Int., v. 181, n. 1, p. $72-87,2008$.

(Manuscript received 03 June 2009; revised 24 August 2009; accepted 25 May 2010) 